\title{
PEMBUATAN DESAIN KOLAM IKAN BANDENG BERBASIS KONSEP BIOSECURITY BAGI MASYARAKAT PETANI TAMBAK DI PESISIR KABUPATEN DEMAK
}

\author{
M. Anas Dzakiy ${ }^{1)}$, Achmad Buchori ${ }^{2)}$, Fafa Nurdyansyah ${ }^{3)}$, Rumiyatun Istiyaningsih ${ }^{4)}$, \\ Velma Nindita ${ }^{5)}$ \\ ${ }^{1,2}$ Fakultas Pendidikan MIPA dan Teknologi Informasi, Universitas PGRI Semarang \\ ${ }^{3,5}$ Fakultas Teknik, Universitas PGRI Semarang \\ ${ }^{4}$ Fakultas Ekonomi dan Bisnis, Universitas PGRI Semarang \\ Email : $\underline{\text { m.anasdzakiy@upgris.ac.id }}{ }^{1}$
}

Key word:

The Milkfish, Wonoagung Village, Biosecurity

\section{Kata Kunci}

Ikan Bandeng, Desa

Wonoagung,

Biosekuriti

\begin{abstract}
The villagers of Wonoagung, Sub-district Karangtengah at Demak Regency are the farmer Community, especially in terms of milkfish farming. The problem of this farming is inadequate harvest of milkfish. This is because the low level of cultivation techniques and an understanding of the threat of disease and pest predators to milkfish. The program aim to find the solution of the problems of the milkfish farmers, training about the concept of Biosecurity for the farmers has been implemented. The enthusiasm of the farmers look very high, many of the problems surrounding the Milkfish cultivation could be answered. The application of Biosecurity is becoming the perfect solution for the Milkfish farmers in the village of Wonoagung Sub-district Karangtengah at Demak Regency in dealing with the threat of either disease or pest predators. The concept of Biosecurity that applied on farmed land include the territorial of waters, air and land of the milkfish environmental farming
\end{abstract}

\begin{abstract}
Abstrak
Penduduk desa Wonoagung, Kecamatan Karangtengah di Kabupaten Demak adalah Komunitas petani, terutama dalam hal budidaya bandeng. Permasalahan yang dihadapi oleh para petani bandeng adalah panen ikan bandeng yang tidak memadai yang dikarenakan rendahnya tingkat teknik budidaya dan pemahaman ancaman penyakit dan predator hama terhadap bandeng. Pengabdian masyarakat dilakukan untuk mengetahui solusi dari permasalahan petani bandeng. Kegiatan yang dilaksanakan adalah pelatihan dan praktik tentang konsep Biosecurity. Antusiasme petani terlihat sangat tinggi, banyak masalah seputar budidaya ikan bandeng yang bisa dijawab. Penerapan Biosecurity menjadi solusi sempurna bagi para petani Bandeng di Desa Wonoagung, Kecamatan Karangtengah, Kabupaten Demak, dalam menghadapi ancaman penyakit dan predator hama. Konsep Biosecurity yang diterapkan pada lahan pertanian mencakup teritorial perairan, udara dan tanah dari lingkungan budidaya bandeng
\end{abstract}




\section{PENDAHULUAN}

Wilayah kepesisiran (coastal area) menurut Sunarto (2001) dalam Yuniastuti (2016) merupakan suatu wilayah yang mencakup wilayah darat dan laut, ke arah laut dibatasi oleh lokasi awal pertama kali gelombang pecah terjadi ketika surut terendah dan ke arah darat dibatasi oleh batas terluar bentuk lahan kepesisiran di pedalaman. Menurut Gunawan dkk (2005) dalam Yuniastuti (2016), wilayah kepesisiran memiliki sumber daya alam yang berpotensi bagi program pembangunan yang berkelanjutan.

Berdasarkan data dari Bappeda Kabupaten Demak (2011) dalam Wacano dkk (2013), secara geografis Kabupaten Demak memiliki lokasi yang berdekatan dengan Kota Semarang, Kabupaten Jepara, Kabupaten Kudus, Kabupaten Grobogan, dan Kabupaten Semarang. Selain itu Kabupaten Demak juga berbatasan dengan Laut utara Jawa. Setidaknya terdapat 4 kecamatan dari 14 kecamatan di wilayah Kabupaten Demak ini berlokasi di wilayah kepesisiran. Kabupaten Demak berkembang khususnya pada sektor perikanan, pertanian, peternakan, perindustrian, perdagangan, dan sektor pengadaan jasa. Wilayah pesisir di Kabupaten Demak memiliki sejumlah potensi besar khususnya berkaitan dengan sektor ekonomi. Banyak wilayah di sepanjang pesisir Kabupaten Demak memanfaatkan lahannya sebagai lahan pertanian dan tambak. Lahan pertanian lebih didominasi oleh tanaman padi, sedangkan lahan pertambakan lebih banyak didominasi dengan usaha ikan bandeng dan udang.

Masyarakat di Kabupaten Demak khususnya wilayah pesisir seperti Kecamatan Karangtengah sangat tergantung oleh perubahan ekosistem yang sangat rentan. Wilayah kecamatan ini dihuni oleh masyarakat yang bekerja sebagai petani tambak khususnya udang windu dan ikan bandeng. Tingginya laju erosi pantai dan kenaikan permukaan air laut menyebabkan banyaknya kerusakan tambak (Wacano dkk, 2013).

Selain perubahan ekosistem yang fluktuatif, faktor lain juga ikut mempengaruhi produksi hasil tambak. Menurut Athirah dkk (2014), faktor pengelolaan tambak menjadi faktor yang mempengaruhi produktivitas tambak. Faktor ini merupakan kompleksitas beberapa unsur parameter yang saling berkaitan antara satu dengan yang lainnya dalam pengelolaan tambak.

Ancaman yang tidak kalah penting bagi usaha tambak adalah penyakit dan hama pemangsa di area tambak. Menurut Azmi dkk (2017), penyakit merupakan 
faktor utama penyebab kegagalan panen pada masyarakat petani tambak akibat kerugian. Hasil penelitian Azmi dkk (2017) menunjukkan bahwa permasalahan kegagalan panen hasil tambak diakibatkan karena petani tambak kurang begitu paham dengan pengetahuan tentang penyakit pada ikan, sanitasi air belum terjaga karena masih mengandalkan air buangan dari tambak lain. Selain itu mekanisme penjagaan tambak dari hama pemangsa juga masih mengandalkan sistem manual sehingga para hama pemangsa masih mudah menerobos masuk untuk memangsa ikan atau udang di tambak.

Kondisi ini menyebabkan perlu adanya pengoptimalan dari sistem tambak khususnya berkaitan dengan penanganan terhadap penyakit dan hama pemangsa. Berkaitan dengan hal ini, maka diadakan kegiatan pelatihan tentang Pengenalan Metode Biosecurity pada Masyarakat petani tambak di wilayah Desa Wonoagung Kecamatan Karangtengah Kabupaten Demak. Kegiatan ini merupakan salah satu rangkaian dari Program Diseminasi yang diselenggarakan oleh Tim Diseminasi Universitas PGRI Semarang dengan pendanaan dari Kemenristekdikti 2017 untuk skema Diseminasi Produk Teknologi.

\section{METODOLOGI PELAKSANAAN}

Kegiatan pelatihan tentang Biosecurity ini dilaksanakan di Balai Desa Wonoagung Kecamatan Karangtengah Kabupaten Demak. Kegiatan ini dilakukan pada bulan Oktober 2017. Peserta dari kegiatan ini adalah para petani tambak ikan Bandeng dari Desa Wonoagung. Metode pada kegiatan ini dilakukan melalui metode ceramah, diskusi terpadu, survei lapangan, pemasangan instalasi Biosecurity, dan pelatihan pemilihan bibit yang unggul. Materi pada kegiatan ini mengacu pada beberapa hal yaitu : metode penggelondongan ikan Bandeng dan pengenalan konsep carrying capasity dari suatu lahan tambak. Selain itu, materi juga mencakup tentang pengenalan alat-alat laboratorium berkaitan dengan pengukuran faktor-faktor fisikokimia lingkungan tambak, dan pengkondisian lahan tambak melalui penerapan Biosecurity.

\section{HASIL DAN PEMBAHASAN}

Ikan Bandeng merupakan ikan yang hidup asli di laut, tetapi kemudian dikembangkan dan dipelihara pada air payau. Habitat aslinya terdapat di wilayah Samudera Hindia dan Samudera pasifik. Ikan Bandeng lebih sering ditemukan secara bergerombol khususnya di sekitar pulaupulau yang berkarang. Ikan Bandeng 
memiliki tubuh yang memanjang dan pipih serta berbentuk torpedo. Mulut ikan Bandeng ini agak runcing, ekor bercabang, dan memiliki sisik-sisik yang halus (Tim Perikanan WWF, 2014).

Desa Wonoagung Kecamatan Karangtengah Kabupaten Demak menjadi sentra ekonomi dalam bidang perikanan khususnya udang windu dan ikan bandeng. Meskipun sudah lama berkecimpung di dunia budidaya ikan Bandeng, masih banyak warga khususnya petani tambak yang masih memiliki kemampuan rendah dalam aplikasi lapangannya. Berkaitan dengan hal tersebut maka tim Diseminasi dari Universitas PGRI Semarang berusaha untuk menjembatani permasalahan tersebut melalui pelatihan. Kegiatan pelatihan yang pertama didahului dengan pemberian materi berkaitan dengan pentokolan ikan Bandeng dan konsep Biosecurity pada lahan tambak ikan Bandeng. Pada kegiatan ini dihadiri oleh sekitar 25 peserta yang sekaligus juga sebagai petani tambak ikan Bandeng dari Desa Wonoagung.

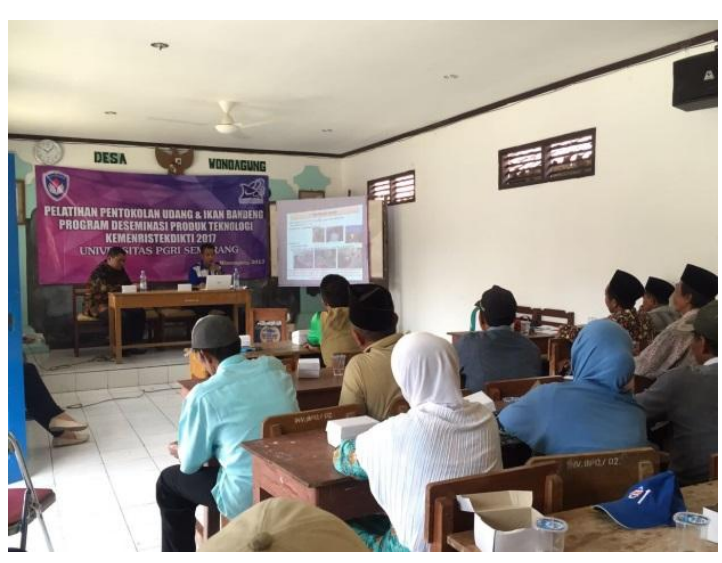

Gambar 01. Kegiatan ceramah dan diskusi mengawali kegiatan pelatihan pentokolan ikan Bandeng dan Biosecurity

Antusiasme warga sangat tinggi dalam diskusi karena mereka selama ini hanya mengandalkan skill yang relatif rendah dalam budidaya ikan Bandeng sehingga resiko kegagalan juga cenderung lebih tinggi. Pada kesempatan ini banyak warga yang mendapatkan pencerahan dan pengetahuan yang tergolong baru berkaitan dengan pemilihan bibit, pengkondisian lahan tambak, dan pengendalian lahan dari gangguan biotik.

Kegiatan kedua berkaitan dengan survei lokasi yang digunakan untuk percontohan dari kegiatan pentokolann berbasis Biosecurity. Pada kegiatan ini, diperlukan lokasi tambak yang tidak terlalu kecil sehingga diharapkan lokasinya lebih leluasa untuk dilakukan pengkondisian. 


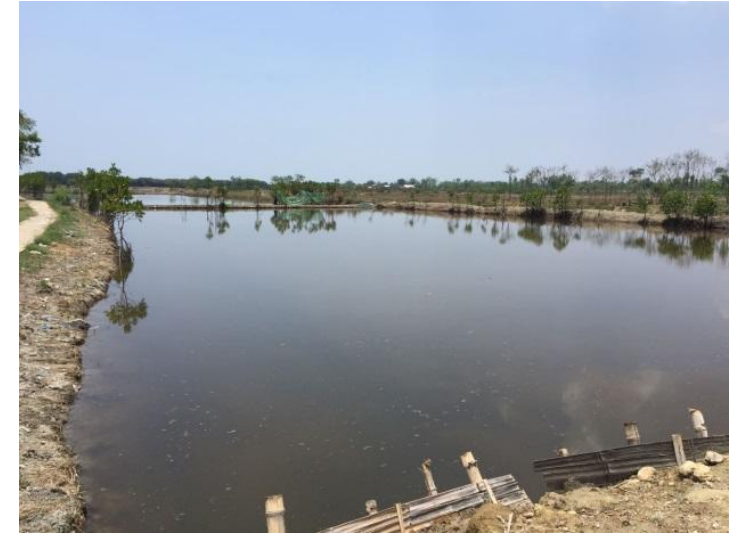

Gambar 02. Lokasi yang digunakan sebagai percontohan kegiatan pentokolan ikan Bandeng berbasis Biosecurity

Kegiatan ketiga adalah praktik Biosecurity melalui pemasangan jaring di seputar lahan tambak. Jaring ini dimaksudkan untuk menghalau predator darat yang masuk dari luar area tambak. Selain itu jaring juga dipasang pada masukan air ke lahan tambak. Pemasangan jaring ini dimaksudkan untuk menghalau predator maupun hama yang masuk melalui jalur air.

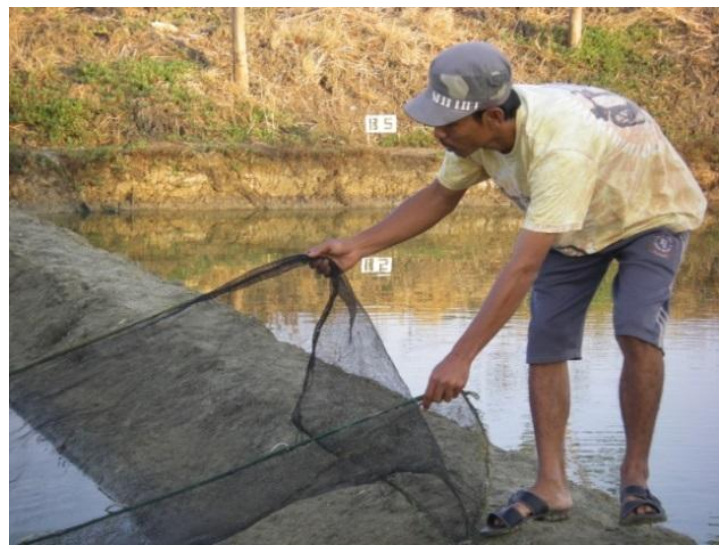

Gambar 03. Kegiatan pemasangan jaring untuk menghalau predator dan hama
Pemilihan bibit menjadi hal yang sangat penting mengingat bahwa resiko kegagalan panen salah satunya dipicu oleh bibit yang tidak unggul. Kegiatan selanjutnya yang juga merupakan bagian dari strategi budidaya berbasis Biosecurity adalah melakukan screening bibit ikan Bandeng yang unggul.

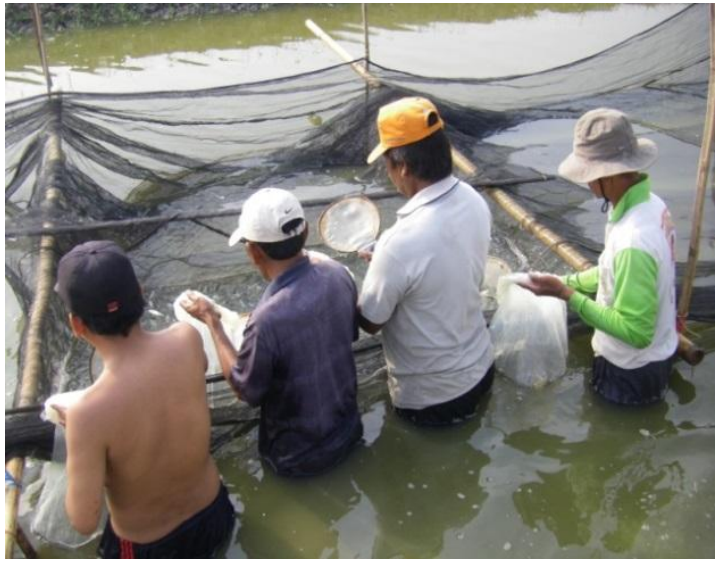

Gambar 03. Kegiatan pemilihan bibir ikan Bandeng yang unggul

Salah satu kendala dari kegiatan pertambakan oleh para petani tambak di Desa Wonoagung tersebut adalah permasalahan berkaitan dengan penyakit dan hama pemangsa. Permasalahan lain dari aktivitas tambak adalah sistem pengelolaan lahan yang belum maksimal dan tidak berbasis pengetahuan yang baik menyebabkan hasil panen tambak menjadi tidak maksimal.

Permasalahan pertama dalam kegiatan budidaya ikan Bandeng adalah tentang penentuan bibit ikan Bandeng berkaitan dengan proses penggelondongan. 
M. Anas Dzakiy, Achmad Buchori, Fafa

Nurdyansyah, Rumiyatun Istiyaningsih, Velma Nindita
Pembuatan Desain Kolam Ikan Bandeng Berbasis Konsep Biosecurity bagi Masyarakat Petani Tambak di Pesisir Kabupaten Demak
Kebanyakan dari para petani tambak ikan Bandeng kurang memahami tentang perkiraan umur dan kondisi ikan Bandeng yang tepat untuk mulai dipelihara di lahan tambak. Kendala yang dihadapi oleh para petani tambak di Desa Wonoagung adalah tidak adanya proses screening terhadap nener ini begitu dibeli dari penjual nener. Nener (larva ikan Bandeng) yang sudah dibeli kemudian langsung segera disebarkan di lahan tambak. Berdasarkan hasil pelatihan, fase umur Nener ikan Bandeng yang tepat dan siap untuk dipelihara adalah mulai berumur 30 hari. Selain itu, syarat lain ditambahkan oleh Tim Perikanan WWF (2014) yang menyebutkan bahwa Nener ikan Bandeng biasanya memiliki panjang tubuh $1 \mathrm{~cm}$. Berkaitan dengan hal tersebut, maka Nener ikan Bandeng yang belum berumur 30 hari atau panjang tubuh kurang dari $1 \mathrm{~cm}$ tidak disarankan untuk langsung masuk ke proses penggelondongan di lahan tambak karena lebih rentan sehingga lebih beresiko mengalami kematian.

Permasalahan kedua dalam kegiatan budidaya ikan Bandeng adalah tentang teknis penggelondongan ikan Bandeng. Banyak petani tambak ikan Bandeng di Desa Wonoagung mengalami kegagalan panen saat proses penggelondongan karena terjadi kematian besar-besaran nener. Berkaitan dengan pemeliharaan ikan Bandeng pada suatu lahan, perlu mempertimbangkan carrying capasity atau daya dukung suatu lahan tambak. Menurut GESAMP (2001) dalam Mustafa dan Tarunamulia (2009), daya dukung didefinisikan sebagai jumlah organisme atau jumlah kegiatan usaha atau produksi total yang dapat didukung oleh suatu area, ekosistem, atau garis pantai yang didefinisikan. Daya dukung lingkungan merupakan nilai kualitas lingkungan yang ditimbulkan oleh interaksi dari semua unsur atau komponen fisika, kimia, dan biologi dalam suatu kesatuan ekosistem (Purnomo,1992 dalam Prasita dkk, 2008).

Ada sejumlah cara dalam menentukan kapasitas maksimal dari carrying capasity pada suatu wilayah termasuk pada lahan tambak. Menurut Widigdo dan Pariwono (2003) dalam Prasita dkk (2008), metode penilaian daya dukung lingkungan bisa didasarkan atas ketersediaan air pada perairan untuk menampung limbah budidaya tambak. Lebih lanjut lagi Rustam (2005) dalam Prasita dkk (2008) mengembangkan metode tersebut dengan penentuan daya dukung lingkungan berdasarkan kandungan oksigen terlarut dengan limbah organik serta kapasitas asimilasi perairan. Kapasitas perairan merupakan kemampuan 
perairan untuk menerima limbah tanpa menyebabkan perairan tercemar. Selain itu, Sitorus (2005) dalam Prasita dkk (2008) menunjukkan alternatif lain dalam mengestimasi penentuan daya dukung lingkungan melalui laju biodegradasi limbah tambak.

Berkaitan dengan kegiatan pelatihan bagi para petani tambak di Desa Wonoagung, mereka belum memahami bagaimana menentukan kondisi lingkungan tambak sehingga belum bisa mengestimasi sejauh mana kapasitas maksimal dari carrying capasity lahan tambaknya. Selain itu, para petani tambak Desa Wonoagung juga belum memiliki keahlian dalam memprediksi berapa perbandingan antara jumlah Nener ikan Bandeng yang disebar dengan kapasitas luasan lahan tambak berkaitan dengan daya dukung lingkungannya. Hal ini menyebabkan terjadinya sejumlah kematian dari Nener ikan Bandeng beberapa hari setelah ditebar di lahan tambak. Solusi yang ditawarkan adalah mencoba untuk mulai mengukur kondisi lingkungan dari aspek faktor fisikokimia lahan tambak sehingga menemukan kekurangan dari lahan tambak tersebut untuk segera diperbaiki. Berkaitan dengan prediksi jumlah Nener yang ditebar, para petani tambak disarankan untuk melakukan pengambilan data untuk melihat perbandingan dari jumlah Nener yang ditebar dan jumlah Nener yang mengalami kematian setelah ditebar. Setiap lahan tambak memiliki kemampuan maksimal dalam menampung sejumlah banyak Nener ikan Bandeng, jika penebaran Nener melebihi jumlah tersebut maka meningkatkan laju kematian Nener ikan Bandeng. Perbandingan antara jumlah Nener siap tebar terhadap luasan lahan tambak adalah sekitar 200-300 ekor/m².

Permasalahan ketiga dalam kegiatan budidaya ikan Bandeng adalah tentang ancaman dari penyakit dan hama pemangsa pemangsa ikan Bandeng. Salah satu faktor yang menyebabkan kurang maksimalnya budidaya ikan Bandeng di wilayah Desa Wonoagung adalah rendahnya pemahaman tentang strategi dalam menghadapi ancaman terhadap penyakit dan pemangsaan oleh hama pemangsa.

Mas'ud (2013) menjelaskan tentang definisi dari CBIB (Cara Budidaya Ikan yang Baik) yaitu cara memelihara dan/ atau membesarkan ikan serta memanen hasilnya dalam lingkungan yang terkontrol. Cara ini dilakukan dengan memperhatikan sanitasi, pakan, obat ikan, dan bahan kimia serta biologis. CBIB dilakukan untuk menjamin mutu dan 
M. Anas Dzakiy, Achmad Buchori, Fafa

Nurdyansyah, Rumiyatun Istiyaningsih, Velma Nindita
Pembuatan Desain Kolam Ikan Bandeng Berbasis Konsep Biosecurity bagi Masyarakat Petani Tambak di Pesisir Kabupaten Demak keamanan pangan hasil pembidodayaan ikan. Lebih lanjut Mas'ud (2013) menjelaskan bahwa dalam budidaya ikan, harus memperhatikan beberapa prinsip yaitu : Biosecurity (keamanan dalam biologi), Food savety (keamanan pangan), dan Environmental friendly (ramah lingkungan). Biosecurity merupakan upaya mencegah atau mengurangi peluang masuknya suatu penyakit ke dalam suatu sistem budidaya dan mencegah penyebarannya dari suatu tempat ke tempat lainnya yang masih bebas.

Menurut Azmi (2017), faktor kegagalan panen pada sektor budidaya perikanan disebabkan oleh penyakit, pencurian, dan kualitas air yang buruk serta bencana alam seperti banjir dan angin topan. Penyakit yang paling berpengaruh terhadap ikan budidaya adalah infeksi virus dan bakteri. Ikan yang sakit menyebabkan petani tambak mengalami kerugian karena harga jualnya menurun. Selain itu, sebaran penyakit karena virus dan bakteri ini menurunkan kualitas air.

Strategi penanganan penyakit dan hama pemangsa tambak yang dikenalkan pada masyarakat petani tambak Desa Wonoagung adalah konsep Biosecurity. Penerapan konsep Biosecurity pada tambak ikan Bandeng dilakukan dalam rangka untuk memaksimalkan hasil panen.
Konsep ini meliputi pencegahan ancaman baik dari air, darat, maupun udara.

Berkaitan dengan konsep Biosecurity bagi ancaman berupa hama dan penyakit pada air, pencegahan bisa dilakukan melalui pemilihan dan penggunaan Nener ikan Bandeng berkualitas yang terbebas bakteri dan virus. Selain itu, strategi lain yang perlu dilakukan adalah dengan penggunaan plankton net (saringan plankton) pada saluran inlet untuk masukan air ke lahan tambak. Strategi ini dilakukan untuk menyaring air sehingga air menjadi terbebas dari organisme seukuran plankton yang biasanya berupa ganggang, bakteri, atau jamur khususnya. Ada beberapa tingkatan Mesh size (ukuran saringan) bagi plankton net. Menurut Umar (2014), untuk menyaring plankton diperlukan mesh size sebesar $35 \mu \mathrm{m}$ bagi kelompok fitoplankton dan $50 \mu \mathrm{m}$ bagi kelompok zooplankton.

Strategi berikutnya adalah melakukan filtering bagi hama dan penyakit kemudian ditampung pada petak tandon yang difungsikan sebagai biofilter. Strategi lain yang perlu dilakukan setelah itu adalah sterilisasi media air yang akan digunakan untuk budidaya ikan Bandeng. Untuk melakukan proses sterilisasi air ini dibutuhkan satu petak kecil didalam lahan tambak yang difungsikan sebagai petak 
tandon. Petak tandon inilah yang nantinya akan diisi oleh air yang akan disterilisasi. Air yang sudah steril dimasukkan ke petakpetak penggelondongan Nener ikan Bandeng.

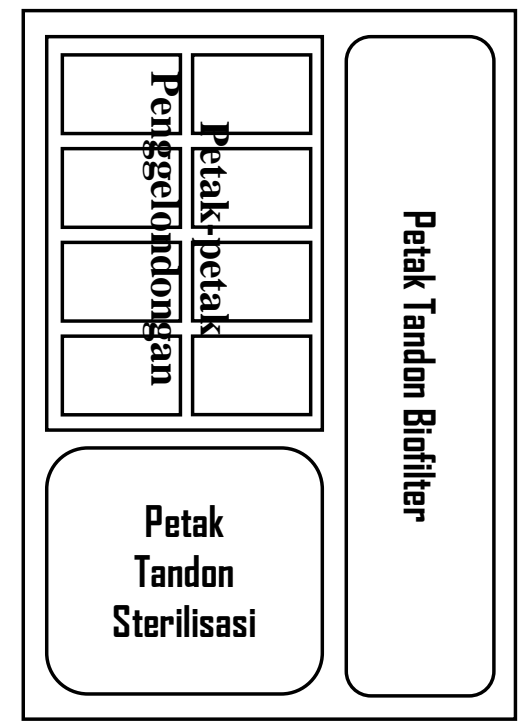

Gambar 04. Desain Layout dari tambak Ikan Bandeng (Romadhona, 2017).

Kebanyakan para petani tambak di Desa Wonoagung belum mengenal prinsip pembagian petak mengacu pada konsep Biosecurity tersebut. Selain itu, berkaitan dengan pemenuhan merdia air bagi budidaya Nener, mereka hanya memanfaatkan aliran air dari lahan tambak di sekitarnya. Kondisi ini menyebabkan sehingga potensi terjangkitnya hama dan penyakit ini menjadi tinggi.

Berkaitan dengan konsep Biosecurity bagi ancaman berupa hama pemangsa yang berasal dari daratan, solusi yang disarankan adalah dengan pemasangan fencing. Fencing ini merupakan pagar yang dibuat secara berkeliling dari bahan jaring untuk menghindari hama pemangsa darat. Menurut Fahmi (2000), hama pemangsa yang biasa memangsa ikan Bandeng dari jenis ular misalnya seperti Cerberus rhynchops dan Fordonia leobalia. Hama pemangsa dari jenis ikan buas misalnya ikan Kakap (Lates calcarifer), ikan Payus (Elops hawaiensis). Menurut para petani tambak di Desa Wonoagung, jenis hama pemangsa daratan yang biasa beredar pada lahan-lahan tambak mereka adalah jenis ular, katak, kadal, dan biawak. Penggunaan Fencing ini diharapkan menjadi solusi untuk menghambat laju pemangsaan ikan Bandeng oleh hama pemangsa darat.

Berkaitan dengan konsep Biosecurity bagi ancaman berupa hama pemangsa yang berasal dari udara, solusi yang ditawarkan adalah penggunaan bahan tertentu seperti plastik yang berbentuk lembaran dan mampu memantulkan cahaya. Sifat dari bahan yang mampu memantulkan cahaya tersebut diharapkan mampu mengganggu penglihatan hama pemangsa dari udara yang akan mencoba memangsa ikan Bandeng. Menurut Fahmi (2000), hama pemangsa yang biasa memangsa ikan Bandeng dari udara adalah beberapa jenis Burung Pecuk (Phalacrocorax javanicus) Burung Blekok (Ardeola rallaoides 
M. Anas Dzakiy, Achmad Buchori, Fafa

Nurdyansyah, Rumiyatun Istiyaningsih, Velma Nindita
Pembuatan Desain Kolam Ikan Bandeng Berbasis Konsep Biosecurity bagi Masyarakat Petani Tambak di Pesisir Kabupaten Demak speciosa), Burung Bangau (Leptotilus javanicus), serta jenis hewan lainnya.

Kegiatan pelatihan tentang Biosecurity ini diharapkan menjadi solusi yang tepat bagi para petani tambak di Desa Wonoagung Kecamatan Karangtengah Kabupaten Demak dalam memaksimalkan potensi lahan tambaknya bagi budidaya ikan Bandeng. Kegiatan ini juga diharapkan menambah wawasan para petani tambak secara umum di wilayah pesisir utara Jawa khususnya pesisir Kabupaten Demak.

\section{KESIMPULAN}

Penerapan konsep Biosecurity menjadi solusi yang tepat bagi para petani tambak di Desa Wonoagung Kecamatan Karangtengah Kabupaten Demak dalam menangani ancaman baik berupa penyakit dan hama pemangsa. Konsep Biosecurity yang diterapkan pada lahan tambak harus meliputi wilayah perairan, daratan dan udara di lingkungan lahan tambak.

\section{SARAN}

Perlu adanya pelatihan lanjutan dan pendampingan secara kontinyu tentang identifikasi faktor lingkungan lahan tambak, dan penerapan teknik Biosecurity secara massal pada lahan-lahan tambak di
Desa Wonoagung Kecamatan

Karangtengah Kabupaten Demak.

\section{UCAPAN TERIMAKASIH}

Ucapan terimakasih kami ucapkan kepada Direktorat Riset dan Pengabdian Direktorat Jenderal Penguatan Riset dan Pengembangan Kementerian Riset Teknologi dan Pendidikan Tinggi; Lembaga Penelitian dan Pengabdian kepada Masyarakat Universitas PGRI Semarang; Pihak Kelurahan dan segenap masyarakat Desa Wonoagung Kecamatan Karangtengah Kabupaten Demak.

\section{DAFTAR PUSTAKA}

Athirah A, Hasnawi, Paena M. 2014. Faktor Pengelolaan yang Mempengaruhi Produktivitas Tambak di Kabupaten Demak Provinsi Jawa Tengah. Prosiding Forum Inovasi Teknologi Akuakultur 2014. Bandung.

Azmi F, Faisal TM, Suransyah A, Sinaga S, Firli A. 2017. Identifikasi Penyebab Kegagalan Panen Petani Tambak : Inventory, dan Implikasi Biosecurity Perikanan Kota Langsa. Samudra Akuatika. 1(2):26-36.

Fahmi. 2000. Beberapa Jenis Ikan Pemangsa di Tambak Tradisional 
dan Cara Penanganannya. Oseana. 25(1):21-30.

Mas'ud F. 2013. Pengembangan Budidaya dan Teknologi Pengolahan Ikan Bandeng (Chanos chanos Forsskal) Di Kabupaten Lamongan Guna Meningkatkan Nilai Tambah. Jurnal Ilmu Eksakta. 1(2):35-58.

Mustafa A, Tarunamulia. 2009. Analisis Daya Dukung Lahan Tambak Berdasarkan pada Kuantitas Air Perairan Di sekitar Kecamatan Balusu Kabupaten Barru Provinsi Sulawesi Selatan. J.Ris. Akuakultur. 4(3):395-406.

Prasita VD, Widigdo B, Hardjowigeno S, Budiharsono S. 2008. Kajian Daya Dukung Lingkungan Kawasan Pertambakan di Pantura Kabupaten Gresik Jawa Timur. Jurnal Ilmu-ilmu Perairan dan Perikanan Indonesia. 15(2):95-102.

Romadhona B. 2017. Produksi Tokolan Udang dan Ikan di Tambak dengan Penerapan Biosecurity. BBPBAP Jepara, Direktorat Jenderal Perikanan Budidaya, Kementerian Kelautan dan Perikanan. Jepara.

Tim Perikanan WWF. 2014. Better Management Practices Seri Panduan Perikanan Skala Kecil : Budidaya
Ikan Bandeng (Chanos chanos) pada Tambak Ramah Lingkungan. WWFIndonesia. Jakarta.

Umar NA. 2014. Mekanisme Pemangsaan Plankton dan Daya Dukung terhadap Kelangsungan Hidup Benur dan Nener di Perairan Pantai Kabupaten Pinrang. Jurnal Balik Diwa. 5(1):4553

Wacano D, Rif'an AA, Yuniastuti E, Daulay RW, Marfai MA. 2013. Adaptasi Masyarakat Pesisir Kabupaten Demak dalam Menghadapi Perubahan Iklim dan Bencana Wilayah Kepesisiran. Chapter Buku Seri Bunga Rampai Pengelolaan Lingkungan Zamrud Khatulistiwa. Kanisius. Yogyakarta.

Yuniastuti E. 2016. Identifikasi Tipologi dan Dinamika, Potensi, dan Permasalahan, dan Strategi Pengelolaan Wilayah Kepesisiran di Wilayah Kepesisiran Demak. Jurnal Geografi. 8(1):31-46 